\title{
Viewing Rome in the Latin Literature of the Ventennio Fascista: Francesco Giammaria's Capitolium Novum
}

\author{
Nicolò Bettegazzi \\ University of Groningen \\ n.bettegazzi@rug.nl \\ Han Lamers \\ University of Oslo \\ han.lamers@ifikk.uio.no \\ Bettina Reitz-Joosse \\ University of Groningen \\ b.l.reitz-joosse@rug.nl
}

\begin{abstract}
This article analyses Francesco Giammaria's Capitolium Novum, a Latin poem describing a tour of the historic center of Rome in 1933, in its historical, architectural, and intellectual contexts. It offers a detailed analysis of three key sections of the poem, which deal with the Colosseum, the Arch of Constantine, and the Ara dei cadutifascisti respectively. The authors show how Giammaria's poem responds to urbanistic interventions in the city center during the ventennio, and specifically to the Fascist 'recoding' of the city as the 'Third Rome', with a narrative emphasizing the historically layered nature of Rome. Giammaria offers his own interpretation of the respective importance and interrelation of the city's historic layers: the rhetoric of his poem is aimed at superimposing Catholic Rome over pagan Rome, and at framing all historical layers of the city, including the Fascist one, as part of its Christian mission and destiny. Thus, Capitolium novum resonates with efforts of intellectuals gathered around Carlo Galassi Paluzzi's Istituto di Studi Romani, who aimed to promote a cultural reconciliation between Fascism and Catholicism.
\end{abstract}




\section{Keywords}

Fascism - Rome - Latin - romanità - Institute of Roman Studies - Francesco Giammaria - Architecture - Catholicism

In this article, we argue that Francesco Giammaria's Capitolium Novum, ${ }^{1}$ a Latin text describing a tour of the historic center of Rome in 1933, can offer significant insights into visions of the city of Rome and the meaning of romanità during the ventennio fascista. Although the text was aimed at a small audience with particular and highly intellectual interests, it represents a sophisticated and independently minded response to recent Fascist urbanistic interventions in the center of Rome. Through our analysis of three key sections of the poem, we show that Giammaria responds to the Fascist recoding of the city as the 'Third Rome' with a narrative which emphasizes the layered nature of the Roman center and offers its own interpretation of the respective importance and interrelation of those historic layers.

\section{1 \\ Capitolium Novum and the Latin Literature of the Ventennio Fascista}

During the ventennio fascista, Italy saw a diverse production of original Latin literature with Fascist themes, ranging from lyric odes in praise of Mussolini to prose orations extolling the new regime, from epics on Italy's martial exploits in Africa to Latin inscriptions on monuments old and new. Recent work has elucidated how the Latin language was accorded special ideological significance during the ventennio and how the regime stimulated its active usage in multiple ways. ${ }^{2}$ Latin was framed as the language of Fascist romanità, as a

1 We cite the poem as $C N$ (for the editions used, see note 5 ). All translations are ours. Francesco Giammaria was born in Anagni, ca. $70 \mathrm{~km}$ south-east of Rome, and learnt Latin at the town's Diocesan Seminary. At the time of the composition of Capitolium Novum, he was working at the Ministero delle Comunicazioni in Rome. For this information, we rely on a letter Giammaria attached to a copy of Capitolium Novum dedicated to the Cardinal Secretary of State Eugenio Pacelli, and now preserved in the Vatican Apostolic Archives (AAV, Segr. Stato, anno 1934, rubr. 256, fasc. 1, ff. $167^{\mathrm{v}}-168$ : see further note 11). During the ventennio Giammaria produced a number of Latin works, listed in note 5 .

2 Apart from the essays collected in Han Lamers, Bettina Reitz-Joosse, and Valerio Sanzotta, ed. Studies in the Latin Literature and Epigraphy of Italian Fascism (Leuven: Leuven University Press, 2019), the most recent works on the topic are Han Lamers and Bettina Reitz-Joosse, Codex Fori Mussolini: A Latin Text of Italian Fascism (London: Bloomsbury Academic, 2016; 
modern and specifically Fascist language, as an international language of communication, and as the language of Italian imperialism. ${ }^{3}$

This article focusses on Francesco Giammaria's Capitolium Novum, a poetic description of a guided tour through the newly 'liberated' and reconfigured heart of the city of Rome: the area between the Piazza Venezia, the Colosseum,

slightly revised paperback edition in 2017) and, by the same authors, 'Lingua Lictoria: The Latin Literature of Italian Fascism,' Classical Receptions Journal 8, no. 2 (2016): 216-252. The place of Latin in Fascist culture is also briefly discussed by Luciano Canfora, Ideologie del classicismo (Turin: Einaudi, 1980), 96, 101-103; Daniela Gionta, 'I certamina di poesia e prosa latina,' in La poesia latina nell'area dello stretto tra Ottocento e Novecento: Atti del convengo di Messina, 20-21 Ottobre 2000 nel centenario della nascita di Giuseppe Morabito (1900-1997), ed. Vincenzo Fera, Daniela Gionta and Elena Morabito (Messina: Centro interdipartimentale di studi umanistici, 2000), 209-223; Jonathan Scott Perry, The Roman Collegia: The Modern Evolution of an Ancient Concept (Leiden: Brill, 2006), 129-131. On the role of Latin in Fascist education in particular see Paolo Fedeli, 'Studio e uso del latino nella scuola fascista,' in Matrici culturali del fascismo: Seminari promossi dal Consiglio regionale pugliese e dall'Ateneo barese nel trentennale della Liberazione, ed. Giuseppe Semerari (Bari: Università di Bari, Facoltà di lettere e filosofia, 1977), 209-224; Gabriella Klein, La politica linguistica del fascismo (Bologna: Il Mulino, 1986), 61-62; Elsa M. Bruni, Greco e latino: Le lingue classiche nella scuola italiana (1860-2005) (Rome: Armando, 2005), 49-99. On individual texts and authors, see Paola Bragantini, 'Il "latinista fascista": Contributo alla biografia di Ettore Stampini,' Quaderni di Storia dell'Università di Torino 2, no. 2 (1998): 61-80; Friedemann Scriba, 'Mussolini-Panegyrik im Alkäischen Vers,' Altsprachlicher Unterricht 46, no. 1 (2003): 38-42; Martje de Vries and Siward Tacoma, 'Stralen als gelijken: De Augustalia (1937) van Anacleto Trazzi,' Roma Aeterna 2, no. 1 (2014): 73-78; Han Lamers, 'Latinizing Mussolini's Message: Nicola Festa's Latin Translation of the "Proclamation of Empire" (1936/7),' International Journal of the Classical Tradition 24, no. 2 (2017): 198-218; Samuel Agbamu, 'The Arco dei Fileni: A Fascist Reading of Sallust's Bellum Iugurthinum,' Classical Receptions Journal 11, no. 2 (2019): 157-177. Sections of the Codex Fori Mussolini are discussed by Peter Aicher, 'Mussolini's Forum and the Myth of Augustan Rome,' The Classical Bulletin 6, no. 2 (2000): 117-140. Some Fascist inscriptions in Latin are studied by Tim Benton, 'Epigraphy and Fascism,' Bulletin of the Institute of Classical Studies. Supplement, no. 75 (2000): 163-192; Flavia Marcello and Paul Gwynne, 'Speaking from the Walls: Militarism, Education and Romanità in Rome's Città Universitaria (1932-35),'Journal of the Society of Architectural Historians 74, no. 3 (2015): 323-342; Antonino Nastasi, Le iscrizioni in latino di Roma capitale (1870-2018) (Roma: Quasar, 2019). Nicolò Bettegazzi (Groningen) is currently working on a $\mathrm{PhD}$ thesis regarding the role of Latin in the negotiation between the political religion of Fascism and Catholicism.

3 Given the historical import of the existence of this production and of some of these individual texts, we are currently preparing the first digital editions for an online publication of Fascist Latin texts, with concise historical introductions and English translations. For up-todate information on this project, co-funded by the University of Oslo, see www.anchoringfascism.com. 
and the Circus Maximus. ${ }^{4}$ The poem consists of $33^{2}$ Latin hexametric lines. It was first published in Rome in 1933 with the subtitle Carmen decennale (referring to the tenth anniversary of Mussolini's regime), and republished in $1934 .^{5}$ The poem opens at the Capitoline Hill, reinvigorated as the center of the city after the erection of the Vittoriano (inaugurated 1911, completed 1925) and the more recent building works in the area:

If you care to climb to the top of the illustrious mountain that preserved the duly hallowed fates of the city, and to look around attentively, you will immediately see before you - how wonderful! - a miracle: Ancient monuments arise, after ruined buildings have been cleared away. The Dux wanted it like this: and the will of the Dux was accomplished ...6

4 On the reconfiguration of the area around the Capitoline Hill during the ventennio, see e.g. Borden W. Painter, Mussolini's Rome: Rebuilding the Eternal City (New York: Palgrave Macmillan, 2005), esp. 21-38; Emilio Gentile, Fascismo di pietra (Rome-Bari: Laterza, 2007), 57-115; Aristotle Kallis, "The "Third Rome" of Fascism: Demolitions and the Search for a new Urban Syntax,' The Journal of Modern History 84, no. 1 (2012): 40-79; Joshua Arthurs, "'Voleva essere Cesare, morì Vespasiano": The Afterlives of Mussolini's Rome,' Civiltà Romana: Rivista pluridisciplinare di studi su Roma antica e le sue interpretazioni 1 (2014): 283-302; Flavia Marcello, 'Forma Urbis Mussolini: Vision and Rhetoric in the Designs for Fascist Rome,' in Brill's Companion to the Classics, Fascist Italy and Nazi Germany, ed. Helen Roche and Kyriakos Demetriou (Leiden-Boston: Brill, 2018), 370-403.

5 Capitolium Novum (Rome: Typographia "Novissima", 1933) - 100 copies; Tria carmina (Rome: Ex Tipis [sic] Novissima, 1934) - 1000 copies. The 1934 edition forms part of the collection Tria Carmina, and in this edition, the subtitle is omitted. Other differences between the two editions are merely of a typographical nature: line 151: eadem (1933)/aedem (1934); line 193: christiadum (1933)/ Christiadum (1934); line 269: opus (1933)/ upus (1934); line 324: Ad nutum Ducis, (1933)/ the comma after Ducis is omitted (1934). Other publications of Giammaria are: Horrida tempestas (79 dactylic hexameters), submitted to the Certamen poeticum Hoeufftianum in 1935, unpublished, preserved in Noord-Hollands Archief in Haarlem (the Netherlands) 64.848, No. 21; Rex «Miles». Carmen ( 76 dactylic hexameters), submitted to the Certamen poeticum Hoeufftianum in 1936, unpublished, preserved in Noord-Hollands Archief in Haarlem (the Netherlands) 64.848 , No. 19. For the attribution of the unpublished work, see Dirk Sacré, 'The Certamen Hoeufftianum during the Ventennio Fascista: An Exploration (With Unpublished Poems by Vittorio Genovesi and Giuseppe Favaro),' in Studies in the Latin Literature and Epigraphy of Italian Fascism, ed. Han Lamers, Bettina Reitz-Joosse, and Valerio Sanzotta (Leuven: Leuven University Press, 2019), 201-243; and Xavier van Binnebeke, 'Hoeufft's Legacy: Neo-Latin Poetry in the Archive of the Certamen poeticum Hoeufftianum (1923-1943),' in Studies in the Latin Literature and Epigraphy of Italian Fascism, ed. Han Lamers, Bettina Reitz-Joosse, and Valerio Sanzotta (Leuven: Leuven University Press, 2019), 247324. On the publishing house that published Giammaria's poems, see Chiara Boschetti, 'Per una storia di Novissima,' Fabbrica del Libro 2 (2012): 31-36.

6 CN1-6: Si super insignis conscendere culmina montis/-Urbis qui sortes servavit rite sacratas - / Pandere et intentus circum tua lumina cures, / Te coram, extemplo - mirum! - portenta videbis: / Assurgunt vetera, abreptis monimenta ruinis. / Sic voluit Dux: et Ducis est confecta voluntas... 


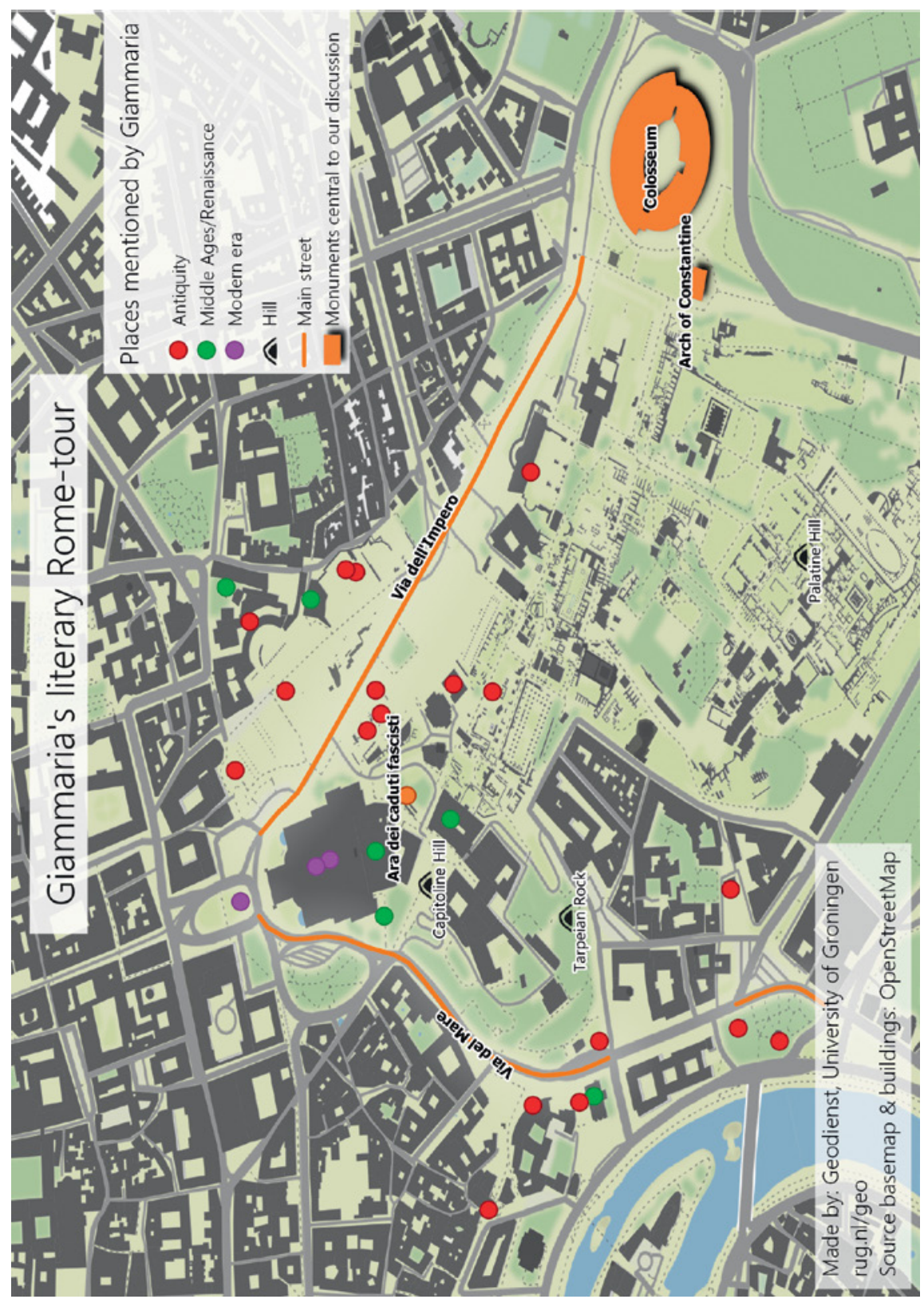

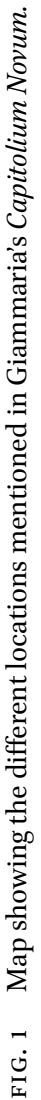


After this opening statement of the reinvigoration of the ancient city of Rome, the narrator leads the reader on a tour of its main sights (Figure 1). Beginning on Piazza Venezia, he first points to the monument of Vittorio Emmanuele II, stressing its celebration of the Unification of Italy and the tomb of the Unknown Soldier. He then leads the reader up the Via dell'Impero (with a short detour up the back of the Capitoline Hill), to the Colosseum and, turning right, the Arch of Constantine, pointing out and interpreting many of the sites - ancient, medieval, and modern - which are to be seen along the way. We then return to the Piazza Venezia and walk up the Via del Mare, again passing numerous ancient and later monuments. The exact route taken by the narrator is partly dictated by the state of the building and demolition works at the time of first publication in 1933: while the Via dell'Impero and the Via del Mare had been opened to the public in 1932, clearing and construction works were still in progress at the Via dei Trionfi until the autumn of 1933 and in the Circus Maximus area until 1934, making an actual circuit around the Capitoline and Palatine Hills impossible at the time of writing. ${ }^{7}$ The poem concludes with an imaginative flight to the seacoast and a reflection on Rome's and Italy's newly restored naval power. The walking tour and inspection of specific sites is several times interrupted by more reflective passages, in which the narrator discourses about the parallels between antiquity and the present or about the victory of Christianity over paganism. ${ }^{8}$ The poem ends with an extended affirmation of the eternity of Rome and of the ancient Latin authors who have immortalized her (implying that Giammaria's work is to fulfil a similarly immortalizing function and join the ranks of ancient authors' works). ${ }^{9}$

What was the intended readership of this remarkable text? ${ }^{10}$ We cannot pronounce on its reception with any certainty, but we would like to argue that this text particularly resonates with the efforts of a group of intellectuals and scholars gathered around the Institute of Roman Studies (ISR). ${ }^{11}$ Founded in

7 Painter, Mussolini's Rome, 31-34.

8 This victory is treated most explicitly in $\mathrm{CN}_{178-196 .}$

$9 \quad C N$ 308-312: Te Venusini carmen alit, cantusque Maronis. / Te Patavini aeterno stylus consecrat aevo, / Suscipis et famam Arpinatis ab ore diserto. / Te Musae cithara mulcent, versuque canoro, / Doctus Apollineo celebrat te carmine coetus... ['The tune of Horace nourishes you, and the songs of Vergil, the pen of Livy consecrates you for eternity, and you receive fame from the well-spoken mouth of Cicero. The Muses flatter you with a cithara, and with melodious verse, the learned crowd celebrates you with an Apollonian poem...'].

10 On the different types of readers of Latin texts during the ventennio, see further Lamers and Reitz-Joosse, 'Lingua Lictoria,' 221-223.

11 We suspect that Giammaria moved in the wider orbit of the ISR, to the presidency of which he personally dedicated a copy of his Tria Carmina, which also contained $C N$ : 'alla 
1925 by Carlo Galassi Paluzzi (1893-1972), the ISR was designed to encourage the academic study and general public knowledge of Rome in all its aspects from antiquity to the present day. Being neither a government organization nor an entirely private enterprise, the institute provided a crucial point of intersection between the realms of politics, academia, and a wider audience. It was naturally dependent on the regime's funding and good will, but also retained an interesting degree of autonomy. In particular, the ISR played an important role in articulating a vision of 'Rome' and 'Romanness' that not only encompassed ancient - and particularly Caesar's or Augustus's - Rome but also Christian and Catholic Rome from late antiquity via the Middle Ages and the Renaissance up to the ventennio. ${ }^{12}$ It is within the wider orbit of the ISR, and within this cultural-political conversation about the scope and meaning of romanità, that we are reading Capitolium Novum. The text may have been read only by a relatively small circle of educated readers, but it represents a sophisticated contribution to a politicized and ideological debate about the city and the 'myth' of Rome.

The poet's choice of the Latin language for participation in this cultural conversation is in itself ideologically significant. For the Institute of Roman Studies

Presidenza dell'Istituto di Studi Romani omaggio. F Giammaria' (handwritten dedication on the 1934 copy of the library of the Istituto Nazionale di Studi Romani, Rome). He also dedicated copies of the poem to Pope Pius XI and to the Cardinal Secretary of State Eugenio Pacelli. The copy dedicated to the cardinal is preserved in the Vatican Apostolic Archive (AAV, Segr. Stato, anno 1934, rubr. 256, fasc. 1, ff. 174-185), with a handwritten dedication on f. 175: 'A Sua Eminenza il Cardinale Eugenio Pacelli, Segretario di Stato di S[ua] S[antità] devoto omaggio, F. Giammaria'.

12 On the ISR and its ideological orientation, see Canfora, Ideologie, 78-81, 91-101; Antonio La Penna, 'La rivista Roma e l'Istituto di Studi Romani: Sul culto della romanità nel periodo fascista,' in Antike und Altertumswissenschaft in der Zeit von Faschismus und Nationalsozialismus: Kolloquium Universität Zürich 14.-17. Oktober 1998, ed. Beat Näf and Tim Kammasch (Mandelbachtal/Cambridge: Cicero, 2001), 89-110; Albertina Vittoria, 'L'Istituto di Studi Romani e il suo fondatore Carlo Galassi Paluzzi dal 1925 al 1944,' in Il classico nella Roma contemporanea: mito, modelli, memoria. Atti del convegno: Roma 18-20 ottobre 200o, 2 vols (Rome: Istituto Nazionale di Studi Romani, 2002), 2: 507-537; Jan Nelis, 'La "fede di Roma" nella modernità totalitaria fascista: Il mito della romanità e l'Istituto di Studi Romani tra Carlo Galassi Paluzzi e Giuseppe Bottai,' Studi Romani 58, no. 1-4 (2010): 359-381; Joshua Arthurs, Excavating Modernity: The Roman Past in Fascist Italy (Ithaca: Cornell University Press, 2012), 29-49. Donatello Aramini, "The Myth of "Christian Rome" and the Institute of Roman Studies: An Attempted Synthesis of Fascism and Catholicism,' Journal of Contemporary History 50, no. 2 (2015): 188-214; Jan Nelis, 'Fascist Modernity, Religion, and the Myth of Rome,' in Brill's Companion to the Classics, Fascist Italy, and Nazi Germany, ed. Helen Roche and Kyriakos Demetriou (Leiden-Boston: Brill, 2018), 140-151. 
in particular, the revival of Rome also entailed the revival of its language, Latin. It encouraged the use of the ancient language both inside and outside Italy. To this effect, it organized a range of activities, including competitions in Latin composition and the compilation of specialized lexica designed to turn Latin into an up-to-date international academic language. ${ }^{13}$ Although Latin was constructed as a modern language, capable of expressing the newest ideas and the most recent developments, Latin writers of this period such as Giammaria often directly adopted phrases and expressions of ancient Latin authors in their works. They did so at least partly for compositional or stylistic convenience. But phrases adapted from classical authors also served to cement the relationship between the Roman past and the Fascist present, and moreover enabled Latin writers to 'anchor' their work in a venerable tradition. ${ }^{14}$ Contemporary Latin authors often engage in intertextual dialogue with a small number of 'favorite' ancient texts: Vergil (especially the Fourth Eclogue, the Georgics, and some sections of the Aeneid) or Horace (above all the Carmen Saeculare). Giammaria's intertextual references, however, while used sparingly, cast a much wider net. Besides Vergil and Horace they include, for example, the less popular Ovid, the imperial author Statius (a favorite of the humanists), the late-antique author Rutilius Namatianus (fl. $5^{\text {th }}$ cent.), and even the inscriptions on the Arch of Constantine, to which we will return below..$^{15}$ This peculiarity connects his use of Latin to his wider vision of Rome: his Latin is not just

13 Lamers and Reitz-Joosse, 'Lingua Lictoria,' 220-221. Carlo Galassi Paluzzi's efforts to promote Latin are briefly discussed in Benedetto Coccia, Carlo Galassi Paluzzi: Bibliografia e appunti biografici (Rome: Istituto Nazionale di Studi Romani, 200o), 12-16; Gionta, 'I certamina,' 211-14; and Perry, The Roman Collegia, 129-131. On the role of the ISR in reviving Latin in the period 1939-1943 as part of the nation-wide educational reforms of the regime, see Fedeli, 'Studio e uso del latino'.

14 Lamers and Reitz-Joosse, The Codex, 23-27.

$15 C N$ 109-110 (of the Basilica of Maxentius and Constantine): Grandius et quidquam, quidquam praestantius ista / Visere non unquam sane potuere Quirites - see Horace, Carmen saeculare 11-12: possis nihil urbe Roma / visere maius; $C N 114$ (of the Colosseum): Surgit in extremis ingenti mole colossus - see Statius, Silvae 1.1 (of a colossal statue of Domitian): Quae superimposito moles geminata colosso / stat Latio complexa forum?; $C N{ }_{15}^{1-15^{2}}$ (on the inscription on the Arch of Constantine, see below): Haec eadem, bene si cernis, fatalia verba, / Isti conveniunt apte quo vivimus aevo... - see Ovid, Fasti 4.255-258 (of an ancient oracle about Cybele, only understood in its proper sense centuries after it was made, when Rome already ruled the world): post, ut Roma potens opibus iam saecula quinque / vidit et edomito sustulit orbe caput, / carminis Euboici fatalia verba sacerdos / inspicit...; CN 298 (of Mussolini):voluntas / Hanc statuere novam rationem ex cardine rerum see Vergil, Aeneid 1.672 (of Juno): haud tanto cessabit cardine rerum; $C N 307$ (of Rome): Appellata solum diversis gentibus unum - see Rutilius Namatianus, De reditu suo 1.63 (of Rome): fecisti patriam diversis gentibus unam. 
the language of Augustan Rome but the language of ancient Rome, Roman Catholicism, and Italian Fascism, and therefore perfectly suited to conveying his layered vision of Rome, to which we will turn next.

\section{Walking Through Rome and Time}

The poem's readers were presumably steeped in classical literature and its reception just as Giammaria himself. They would therefore immediately have recognized the literary tradition which his text evoked. Although Giammaria did not follow one specific model or include copious citations of ancient authors, Capitolium Novum, by its very subject matter, evokes a long tradition of ancient and later literary 'guided tours through Rome'. For example, in the eighth book of Vergil's Aeneid, the Arcadian king Evander famously leads Aeneas to some of the sights of proto-Rome, among them the Capitoline Hill (still without buildings, yet already a numinous place), the site of the future Forum Romanum (where cattle still graze), and the Palatine (where the Arcadian king's simple hut prefigures the home of Augustus in Vergil's own time). This genre of the 'literary guided tour' through Rome, thus established, is developed by several authors both in antiquity and later, especially during the Renaissance. ${ }^{16}$

A common characteristic of the Rome-tour genre of any period is a form of 'time-lapse': the superimposition of different periods on each other during the walk around the city. Vergil, for example, describes the pre-Roman wilderness of Aeneas' time, but also points to the sights of Augustan Rome, actually visible in the same places to his readers. The Augustan poet Propertius, in a poem which responds to Vergil's scene, invites a stranger to survey the new, Augustan city of Rome, while asking him to compare what he sees to the simple, rural beginnings of the place (Elegies 4.1). Renaissance authors often tend to stress the contrast between the neglected aspect of Rome's ancient center in their own time and the now invisible glory of ancient Rome: through centuries of neglect ancient buildings have crumbled or disappeared. Another prominent theme of Renaissance 'tours' is the contrast between the now prostrate remains

16 Famous ancient Rome-tours are Vergil, Aeneid 8.306-369, Propertius, Elegies 4.1, Ovid, Tristia 3.1, and Ammianus Marcellinus 16.10.13-15. On the literary tradition of Rome-tours, see, Ulrich Schmitzer, 'Literarische Stadtführungen: von Homer bis Ammianus Marcellinus und Petrarca,' Gymnasium 108 (2001): 515-537; Andrew Hui, 'The Textual City: Epic Walks in Virgil, Lucan, and Petrarch,' Classical Receptions Journal 3, no. 2 (2011): 148-165. For a discussion of some important Renaissance Rome-tours, with particular attention to the reception of Vergil, see Susanna T. M. de Beer, 'In the Footsteps of Aeneas: Humanist Appropriations of the Virgilian Walk through Rome in Aeneid 8,' Humanistica Lovaniensia 66 (2017): $23-55$. 
of an ancient, pagan Rome and the triumphant sites of the later, Christian Rome. ${ }^{17}$

The city of Rome consists of a multitude of almost intractable historical and physical layers, an intractability that famously inspired Sigmund Freud, in Das Unbehagen in der Kultur (1930), to imagine what it would be like to be able to look at all of these layers at once:

Where the Coliseum stands now we could at the same time admire Nero's Golden House; on the Piazza of the Pantheon we should find not only the Pantheon of today as bequeathed to us by Hadrian, but on the same site also Agrippa's original edifice; indeed, the same ground would support the church of Santa Maria Sopra Minerva and the old temple over which it was built. ${ }^{18}$

Given the palimpsestic nature of the city, it is hardly surprising that at the heart of the Rome-tour genre lies the question 'which Rome am I looking at?', and that the answer is almost never just 'one' Rome. Looking at the eternal city means looking through history, and yet we cannot (except in Freud's famous thought experiment) see all of its history at the same time. Every tour selects, emphasizes, and privileges some elements and periods of Rome, while others fade into the background.

Giammaria's poem places itself within this literary tradition of Rome-tours and adopts some of its most important features, including the contrast between the past and the present, the element of time-lapse, and the 'layering' of pagan, Christian, and contemporary Rome. The question 'which Rome?' also lies at the heart of his poem and plays directly into urbanistic and culturalpolitical developments at the time of his poem's composition. It has been argued that the radical reconfiguration of the city in the 1920s and (especially) 1930s, including demolitions, constructions of new buildings, and reconstructions of historical ones, was aimed at 'a wholesale recoding of the (existing)

17 De Beer, 'In the Footsteps,' $36-37$.

18 Sigmund Freud, Civilization and Its Discontents, authorized translation by Joan Riviere (London: Leonard \& Virginia Woolf at the Hogarth Press and The Institute of Psychoanalysis, 1930), 18. Original German text in Das Unbehagen in der Kultur (Vienna: Internationaler Psychoanalytischer Verlag, 1930), 15. On this passage in connection with ancient and later Rome-tours, see Catharine Edwards, Writing Rome: Textual Approaches to the City (Cambridge: Cambridge University Press, 1996), 27-28; Hui, 'The Textual City,' 148150. See also Kallis, 'The "Third Rome", 43: 'Inside the historic center of post-unification Rome, rival histories and memories, dissonant architectural styles and layers, viscerally opposed jurisdictions, and competing visions for the future clashed for spatial-visual and symbolic dominance.' 
city as a spatial and visual container of symbolic (Fascist) meaning. ${ }^{19}$ By erasing the remnants of certain historical periods and by reframing, reconstructing and emphasizing others, the regime was 'seeking to "reclaim" the ideal essence of its illustrious predecessors, 'carefully redacting a palimpsest of urban layers forged across millennia of history and then subsuming it into a single, all-embracing narrative of Roman and Fascist universality.'20

Giammaria reacts to this ideological architectural program. In his guided tour, he embraces and emphasizes the historically layered nature of the Roman cityscape, offering his own, equally careful (literary) redaction of the city's palimpsest. In doing so, Giammaria seems to modify the overall narrative of the Fascist urban interventions, complicating the regime's 'recoding' of the city as a symbol of Fascist universality. His layered image of the city includes its ancient, late-antique, medieval, early modern, and modern strata, but Giammaria offers his own interpretation of the respective importance and interrelation of those historic layers. In particular, his rhetoric is aimed at superimposing Catholic Rome over pagan Rome and at framing all historical layers of the city, including the Fascist one, as part of its Christian mission and destiny. While the poet repeatedly emphasizes that the 'will of the Dux' has been accomplished, ${ }^{21}$ and depicts Mussolini as the driving force of Rome's transformation, ${ }^{22}$ he also frames Fascist Rome as part of a larger, divine plan for the world. In this way, Giammaria's poem exposes a tension between Fascist and Catholic claims to the city as symbol and guarantor of universality, a tension which is never entirely solved in the poem.

In Giammaria's guided tour, three monuments are made to stand out as especially significant by the length and rhetorical elaboration of their descriptions: the Colosseum, the Arch of Constantine, and the Ara dei caduti fascisti [Altar to the Fallen Fascists]. For each monument, Giammaria emphasizes the layered nature of the Roman cityscape and depicts the interrelation of these historical layers in different ways. His discussion of the Colosseum emphatically contrasts ancient pagan with Christian Rome, whereas his representation of the Arch of Constantine melds late-antique with contemporary Fascist Rome. His discussion of the Ara dei cadutifascisti focuses on the recent Fascist interventions in the ancient cityscape. Together, these descriptions form a complex layered image of the city.

\footnotetext{
19 Kallis, 'The "Third Rome", 44.

$20 \quad$ Kallis, 'The "Third Rome", 44, 78.

21 CN 6, 65-68, 160-162.

$22 \mathrm{CN} 287-304$.
} 
A colossus with a huge mass rises at its end (i.e. of the Via dell'Impero), made of Tiburtine stone, and also splendid in craftsmanship, executed with arches constructed in three tiers, an astonishing thing: erected on an immense base, lofty and outstanding it raises its top to the skies. However, even if these wonders were once symbols of a mighty people, reminders of human suffering are not absent $\ldots{ }^{23}$

Thus begins Giammaria's description of one of the most iconic monuments of Rome, the Colosseum. The poet mentions the monument's magnificence and presents it as evidence that the Romans were a 'mighty people'. But he immediately adds that the monument is also reminiscent of 'human suffering'. He then evokes, rather graphically, the Christian martyrs who were reportedly persecuted there under the Roman emperors:

In this arena, warm blood of men flowed, because the cruel, blood-thirsty masses demanded it. Now, remembering the past, you can actually hear the sound of the moment when, with a downturned thumb, the cruel masses rejoiced in seeing struggling men killed. Here also the invincible Christians, engaged in a harsh battle, preferred to suffer burnt bodies and shattered limbs, for the sake of the triumph of the sacred Cross, and to sanctify their unshaken faith with the seal of death. ${ }^{24}$

The poet turns the Colosseum into a monument of Christian triumph over pagan antiquity, drawing on the building's long history as a Christian

23 CN 114-120: Surgit in extremis ingenti mole colossus, / E tiburtino saxo, simul arte superbus, / Arcubus extructis perfectus in ordine triplo: / Portenti genus: immensaque crepidine fixus, / Arduus et praestans protendit ad aethera culmen. / Haec modo si fuerant validae signacula gentis, / Nec desunt tamen humani monimenta doloris...

24 CN 121-128: Hac hominum tepidus sanguis perfusus arena, / Sanguine cum sitiens hoc plebs truculenta petebat. / Nunc memor auscultas strepitus cum, pollice verso, / Luctantes gaudet plebs dira videre necatos. / Hic quoque Christiadae, durum certamen adorti, / Corpora combusta, invicti, lacerataque membra / Pro Crucis augustae malunt sufferre triumpho, / Servatamque fidem mortis sacrare sigillo. A very similar image is elaborated in Vittorio Genovesi's Imperii Via ad Clivum Capitolinum (1934). In the same way as Giammaria, the Jesuit poet walks down Via dell'Impero and, when stopping in front of the Colosseum, recalls - though in a less triumphalist tone - Christian martyrdom (56-64): Flavii recta venies theatrum, / illitum crebro pugilum cruore, / dira quos matrona neci vovebat / pollice verso. / Martyr immiti moriturus illic / fausta tortori prece flagitabat, / aemulum dura gladiator illic / stravit arena. 
monument. ${ }^{25}$ The early sixteenth century had seen the construction of a small chapel at the east end of the arena (the Santa Maria della Pietà), and in the 167os Gianlorenzo Bernini (1598-1680) even planned a church of the martyrs in the middle of the arena. During the Jubilee of 1675 , Pope Clement x (r. 16701676) had a large wooden cross raised on top of the building, and Pope Benedict XIV (r. 1740-1758) formally declared the Colosseum a sacred site, banning its use as a quarry for building material. ${ }^{26}$ In 1749 , a cross was installed in the middle of the arena. During the Jubilee of the following year, Benedict had the Stations of the Cross erected and ordered a marble plaque to be placed on the monument's west wall. In this inscription, which reproduced an earlier, painted version put up under Clement $\mathrm{X}$, the Colosseum was celebrated as 'redeemed by the blood of the martyrs from foul superstition' (martyrum cruore ab impura superstitione expiatum). ${ }^{27}$ Through this inscription, the monument was further, and more lastingly, transformed into a symbol of the Christian triumph over paganism. Giammaria emphasizes this tradition, ending his passage on the Colosseum on a triumphalist note with a passionate invocation of the cross:

Thus, with justice now rises the stem of the Cross in that place, which has been glorified by the blood of Saints: here it remains, here it shines, fixed in the sacred arena; here it remains, here it shines as a trophy of faith and hope. ${ }^{28}$

Giammaria's emphatic invocation of the 'stem of the Cross' (Crucis truncus) also had a specific contemporary resonance. While Benedict's cross had been removed in the 1870 s under state sponsorship, a new wooden cross had been installed at the north side of the arena under the auspices of the Fascist regime in 1926 (Figure 2). ${ }^{29}$ Four Latin inscriptions were placed beneath it. ${ }^{30}$

25 See Urich Sinn, 'Das Colosseum: Der Tod des Gladiators,' in Erinnerungsorte der Antike: Die römische Welt, ed. Elke Stein-Hölkeskamp and Karl-Joachim Hölkeskamp (Munich: Beck, 2006), 434-437; Keith Hopkins and Mary Beard, The Colosseum (London: Profile Books, 2006), 167 .

26 Hopkins and Beard, The Colosseum, 160-164.

27 The complete text of the inscription can be found in Tyler Lansford, The Latin Inscriptions of Rome: A Walking Guide (Baltimore: The John Hopkins University Press, 2009), 72-73.

28 CN 129-132: Jure igitur Crucis emergit nunc truncus in isto / Qui locus est factus Sanctorum sanguine clarus: / Hic manet, hic fulget sacra defixus arena, / Hic manet, hic fulget fideique speique trophaeum.

29 Hopkins and Beard, The Colosseum, 175.

3o The four inscriptions are as follows: (1) CRVCI VETVSTAE / ANNO [IVBILAEI MDCCL] / AVCTORE S. LEONARDO A PORTV MAVRITIO / FLAVIORVM AMPHITHEATRO / A MAIORIBVS PIENTISSIME IMPOSITAE / OB TEMPORVM FORTVNAM OBLATAE / HAEC 


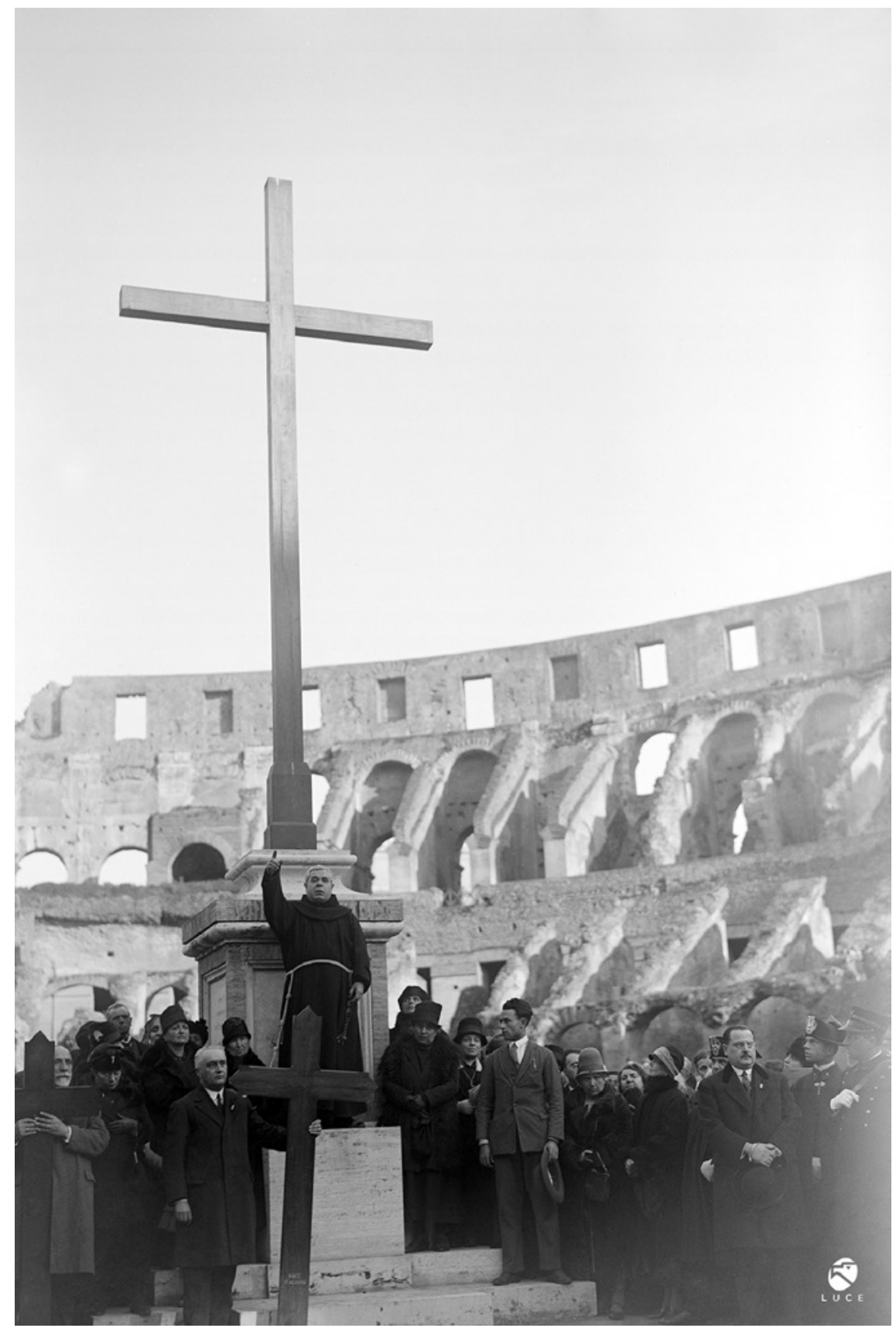

FIG. 2 A monk blesses the faithful gathered around the cross in the Colosseum (31 March 1928).

SOURCE: ARCHIVIO LUCE, A00002518. 
One read AVE / CRVX / SPES VNICA, taken from Vexilia Regis, a hymn by the Merovingian poet and Bishop of Poitiers Venantius Fortunatus (ca. 530-ca. 6o9); 31 another one mentioned the removal of the Cross in the nineteenth century and its restoration in the Fascist era. Two more inscriptions specified the date of the new installation according to four different chronological -Christian and Fascist - conventions. In this way, the Fascist regime had attempted to reframe the monument's Christian significance as part of a Fascist message.

Giammaria's emphatic nunc [now] clearly refers to the very recent restoration of the cross. However, only with this single word does the poet acknowledge the regime's carefully orchestrated and widely publicized reinstallation of the cross. ${ }^{32}$ The picture that emerges of the Colosseum shows us the different historical layers and meanings of the monument, including the most recent intervention, but in weighting their relative importance, Giammaria's eloquent silence on the regime's re-erection of the cross denies this gesture its intended import of recoding the monument as symbolic capital of Mussolini's 'Third Rome'.

Giammaria's representation of the Colosseum primarily as a testimony to Rome's Christian history is consistent with the poem's general emphasis on the city's Christian tradition and its role in God's plan. This is also reflected in Giammaria's discussions of other monuments with a Christian history, such as

NOVA SVFFICITVR / REI PVBLICAE AC CIVITATIS MODERATORIBVS / OPTIME IVVANTIBVS / ANNO DOMINI MCMXXVI. (2) ANNO V / PONTIFICATVS / PII XI PONT. MAX. / A CHRISTI CRVCE / PER HELENAM AVG. RECVPERATA / SAECVLARI XVI. (3) ANNO XXXVI / PRINCIPATVS / VICTORII EM. III REGIS / AB ITALIA / BENITO MVSSOLINI DVCE / INSTAVRATA ATQVE RENOVATA / ANNO IV. (4) AVE / CRVX / SPES VNICA. [(1) 'With the fine help of the rulers of the nation and the city, this new cross is chosen to substitute the old one which in the Jubilee year of 1750 , with the effort of San Leonardo da Porto Maurizio, was piously placed by the ancestors in the Flavian amphitheater and later taken away by the vicissitudes of time.' (2) 'In the fifth year of the pontificate of Pius XI [i.e., 1926], sixteen centuries after Helen's recovery of Christ's Cross [i.e., 326].' (3) 'In the thirty-sixth year of the kingdom of Vittorio Emanuele III; in the fourth year from the renewal of the Italian nation under Benito Mussolini's leadership.' (4) 'Hail to the Cross, our only hope"']. Source: 'Il ritorno della Croce al Colosseo,' newsreel produced by Instituto Nazionale Luce, 1926 (retrieved 30/o9/2018), 21:50 mins. (mute, B/W). Archivio Luce, Rome, Moo6701. The Latin inscriptions are shown towards the end of the newsreel, between minutes 19:39 and 20:52.

31 See Catholic Encyclopedia, s.v. 'Vexilia Regis Prodeunt', accessed October 28, 2018, www .newadvent.org/cathen/15396a.htm.

32 We do find an allusion to Mussolini as defender of the Cross (and Catholicism in general) in In Laudem Beniti Mussolini, the opening poem of Giammaria's 1934-trilogy (lines 9-10): Te Duce, Christiadum potuit spectare serena / Turba refulgentem tempus in omne Crucem. 
Trajan's Column, which was erected in 113 to commemorate the Emperor's victory over the Dacians:

Nearby [the Via dell'Impero] a high column still stands, part of an ancient basilica, engraved in a spiral with various warlike figures. The Emperor built it after conquering the Dacians, so that it could keep his burned ashes after his death. Now the statue of the divine Key-Bearer shines on its top, to show the people a sacred new triumph. ${ }^{33}$

In Giammaria's interpretation, Trajan's military triumph over the Dacians is surpassed by the triumph of Christianity. This sacrum and novum triumphum is symbolized by the bronze statue of St. Peter which Pope Sixtus V (r. 15851590) had installed on top of the column in 1587 to replace the long-lost statue of the Emperor himself.

\section{Arch of Constantine}

While the Colosseum offered Giammaria an opportunity for playing ancient (pagan) and Christian Rome off against each other, both 'Romes' naturally coincide in his depiction of the Arch of Constantine, a famous monument to the first 'Christian' emperor (Figures 3 and 4). Moreover, Giammaria also presents the arch as a prophetic monument to Mussolini and his Third Rome. Through his depiction of the Arch of Constantine, Giammaria thus rhetorically ties together ancient, Christian, and Fascist Rome. ${ }^{34}$

$33 C N$ 35-40: Hic prope, pars aulae veteris, manet alta columna / Belligeris variis in gyrum insculpta figuris. / Dacicus hanc Princeps victor construxerat olim, / Illius ut cineres post fata teneret adustos. / Clavigeri divi nunc fulget vertice signum, / Gentibus ut monstret sacrumque novumque triumphum.

34 For such a rhetorical tour-de-force, the Arch of Constantine appears to be a fitting and interestingly self-aware choice, since its sculptural decoration combines spolia from monuments of Hadrian, Trajan, and Marcus Aurelius with contemporary relief sculpture in order to place Constantine in a tradition of good emperorship which transcends the centuries. On the Arch of Constantine see Hans Peter L'Orange and Armin von Gerkan, Der spätantike Bildschmuck des Konstantinsbogens (De Gruyter: Berlin, 1939); Diana E. E. Kleiner, Roman Sculpture (New Haven: Yale University Press, 1992), 444-455 with bibliography. On the meaningful use of spolia on the arch, see e.g. Jas Elsner, 'From the Culture of Spolia to the Cult of Relics: The Arch of Constantine and the Genesis of Late Antique Forms,' Papers of the British School at Rome 68 (2000), 149-184. 


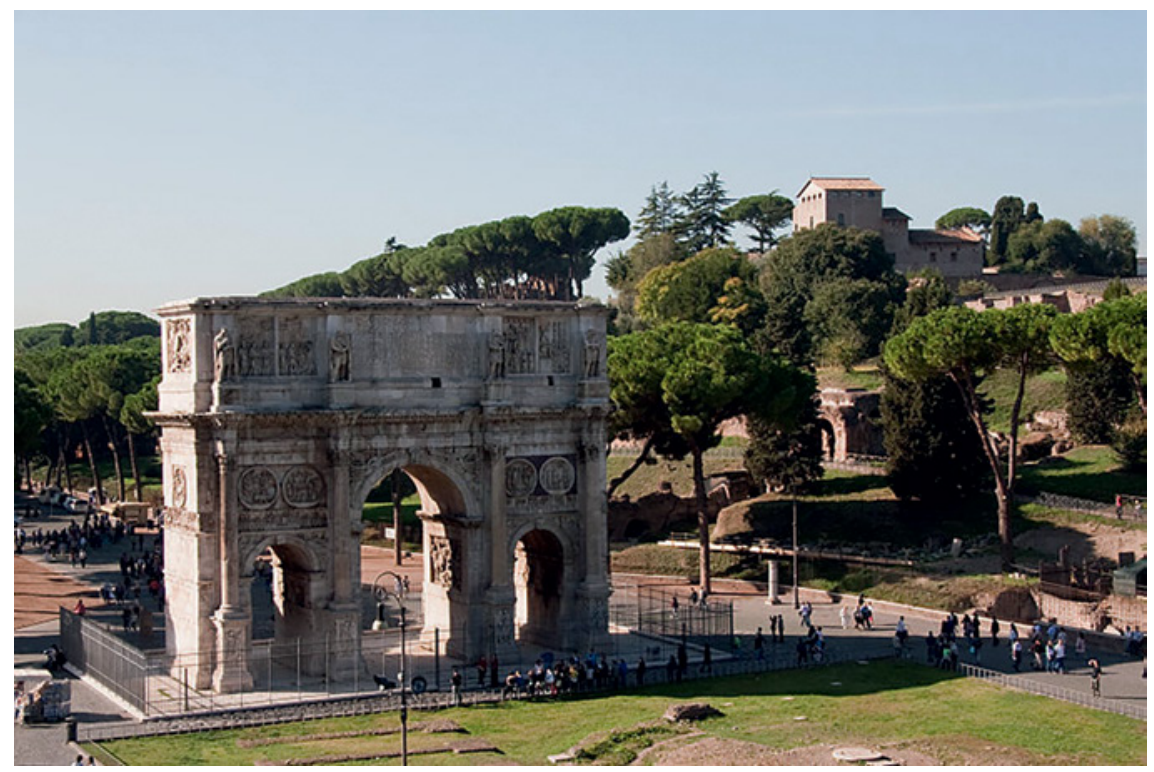

FIG. 3 Arch of Constantine. Photographer: Maros Mraz.

SOURCE: WIKIMEDIA COMMONS. LICENSED UNDER THE CREATIVE COMMONS ATTRIBUTION-SHARE ALIKE 3.0 UNPORTED LICENSE.

In the first section of the passage, ${ }^{35}$ the narrator points out the monument, isolated in the recent clearing operations, and recalls the reason for the senate's dedication of the arch in AD 315: Cum patriam fortis servaverat, hoste repulso (line 146) - an obliquely abridged version of the battle of the Milvian Bridge and Constantine's victory over Maxentius in $312 .^{36}$

While the fascinating decorative program of the arch remains entirely unmentioned, the next, intriguing lines draw our attention especially to the inscriptions on the arch: "The words you see on both sides above the sculpted

35 CN 144-146: Ecce triumphalis bifrons extollitur arcus, / Quem Constantino statuit sacrare Senatus, / Cum patriam fortis servaverat, hoste repulse ['Behold, a two-faced triumphal arch is elevated, which the Senate decided to dedicate to Constantine, since he bravely drove back the enemy and saved the fatherland'].

36 Giammaria epitomized the inscription's already concise formulation quod instinctu divinitatis, mentis / magnitudine, cum exercitu suo / tam de tyranno quam de omni eius / factione, uno tempore, iustis / rem publicam ultus est armis (CIL 6.1139). The arch refers to Constantine's opponent Maxentius only in general and oblique terms (tyrannus, factio). Giammaria's further generalization (hoste) paves the way for the later parallel between Constantine and Mussolini by eliding the difference between the kinds of 'enemy' they faced in marching on Rome. 


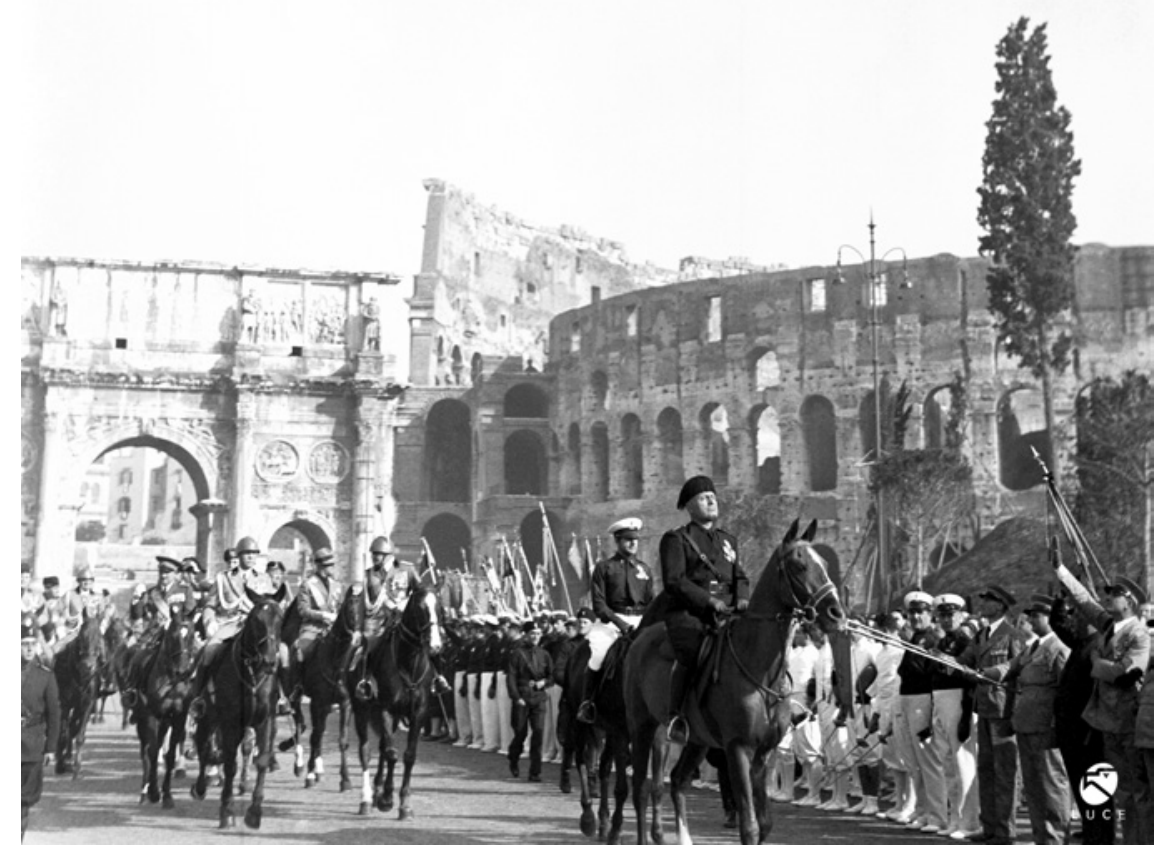

FIG. 4 Mussolini reviews athletes in Via di San Gregorio with the Arch of Constantine and the Colosseum in the background. The event took place during the anniversary of the Fascist revolution and the inauguration of the new Via del Circo Massimo (28 October 1934). The road was still under construction when Giammaria wrote Capitolium Novum.

SOURCE: ARCHIVIO LUCE, A00057492. 
stone celebrate the Divine bringer of liberty and peace as a victor, and greet him with gratitude.'37 Giammaria here refers to the two short inscriptions on facing sides of the interior of the portal, reading liberatori urbis ['to the liberator of the city'] and fundatori quietis ['to the founder of peace'] respectively, but the reference to the 'celebration of the victor' conflates this with a reference to the large inscription on both sides of the arch, which famously praises Constantine for his victory over Maxentius.

The narrator then introduces a particularly marked form of time-lapse, by claiming that the words of the inscription, which he now calls fatalia verba, 'words of fate' or 'prophetic words', refer not only to Constantine, but also suit the present age and in fact describe the leader of Fascism, Benito Mussolini:

After so many things have happened and so much time has passed, these same words, prophetic, if you look at them well, perfectly suit the age we live in and represent a man of our time with a strong mind. For he too secured the Fatherland, which was suffering from misfortune, and safely brought it back into one body, strenuous and warlike, stern, and rejecting the sluggish. ${ }^{38}$

The reference to Mussolini's robusta mens picks up Constantine's magnitudo mentis in the inscription, and in what follows, manly force and energy and the achievement of uniting and steadying the fatherland in a crisis are all attributed to the arch's original dedicatee as well as to Mussolini. A reference to the decennalia, the celebration of the tenth anniversary of the March on Rome, ${ }^{39}$ forms the quick transition to the elaborate description of a modern triumphal procession, featuring Mussolini as the protagonist of the spectacle:40 'He was the Leader, and with his head held high, he led the mutilated soldiers, bearing

37 CN 147-149: Verba super saxo insculpto quae cernis utrinque / Et libertatis Divum pacisque datorem / Victorem celebrant et grata mente salutant.

38 CN 150-156: Post tantos casus, tantum post temporis orbem, / Haec eadem, bene si cernis, fatalia verba / Isti conveniunt apte quo vivimus aevo, / Praesentemque virum robustae mentis adumbrant. / Is quoque nam Patriam, misera sub sorte dolentem, / Corpore firmavit tutamque redegit in uno, / Strenuus et pugnax, rigidus, tardosque recusans.

39 CN157-159,

40 The arch was used for triumphal processions in 1933 at the opening of the new Via dei Trionfi and again in 1938 when Hitler visited Rome: Rolf Quednau, 'Costantino il Grande a Roma: Forme e funzioni della memoria nelle testimonianze visive da Ponte Milvio a Mussolini,' in Costantino il Grande tra medioevo ed età moderna, ed. Giorgio Bonamente, Giorgio Cracco, and Klaus Rosen (Mulino: Bologna, 2008), 384-386. 
arms, with a serious face and his arm raised high., ${ }^{41}$ While the author thus makes explicit a number of the parallels between Mussolini and Constantine, further coincidences, not referred to explicitly, link both men through the arch of Constantine: Constantine's arch had also been dedicated in celebration of the tenth anniversary of his reign, and the date of the March of Rome (and hence of the decennale) was the 28th of October, which is also the date of the battle at the Milvian bridge.

Such parallels between Mussolini and Constantine were not lost on Fascist ideologues. While the roles of Caesar or Augustus in the Fascist cult of Rome are of course well known, the role of Constantine has been less explored. ${ }^{42}$ Parallels between Constantine and Mussolini became especially popular once the Lateran Pacts had (for a time) resolved the conflict between the Italian State and the Church in 1929. Mussolini's perceived role in bringing about the historic agreement was sometimes even explicitly compared to Constantine's Edict of Milan. For example, the archbishop of Milan, Cardinal Ildefonso Schuster, claimed that, after sixteen centuries, a second March on Rome had occurred and a second 'religious pact' had been established, linking Mussolini to the spiriti magni of both Constantine and Augustus. ${ }^{43}$

While Giammaria does not go this far, his poetic depiction of the Arch clearly draws on similar ideas, such as his claim that the inscriptions on the Arch of Constantine are verba fatalia written in the distant past and destined to be fulfilled in the present. Contemporary parallels for such a notion abound: for example, in 1933, Giuseppe Forchielli (1885-1969), the author of Mussolini e la religione [Mussolini and Religion, 1933], described Mussolini as 'the man, sent by Providence, who reveals new destinies to us; the great father, the high priest

$41 \quad C N$ 166-167: Dux erat: et mutilos alta cervice praeibat, / Arma gerens, vultuque severo, erectus in armo.

A few exceptions are Lorenzo Braccesi, 'Costantino e i Patti Lateranensi,' Studi Storici 32, no. 1 (1991): 161-167 and, by the same author, Roma Bimillenaria: Pietro e Cesare (Rome: L'Erma di Bretschneider, 1999), 170-176. More recently, see Alberto Guasco 'Il "nuovo Costantino" fascista: Immagini e utilizzi dell'imperatore tra chiesa cattolica e regime,' in Costantino I. Una enciclopedia sulla figura, il mito, la critica e la funzione dell'imperatore del cosiddetto editto di Milano, 313-2013, 3 vols (Rome: Istituto dell'Enciclopedia Italiana, 2013), 3: 469-480; Aramini, 'The Myth of "Christian Rome", 200-201; Lucia Ceci, The Vatican and Mussolini's Italy (Leiden-Boston: Brill, 2016): 168-170.

43 'Dopo 16 secoli, ecco un'altra marcia su Roma, ed ecco un altro editto di pace religiosa, di quella pace che è stata firmata nel Trattato del Laterano, e che dando a Dio l'Italia, ha dato all'Italia Dio ... Dio ha voluto dare anche al Duce un premio che riavvicina la sua figura storica agli spiriti magni di Costantino e Augusto, recingendo, per opera di Benito Mussolini, Roma e il Re di un nuovo rigoglioso lauro imperiale.' 'La via trionfale da $\mathrm{Au}-$ gusto a Costantino,' Il Popolo d'Italia, February 27, 1937. 
[pontefice] of the Fatherland, finally rediscovered; a new Constantine.44 Just as Forchielli, who calls Mussolini a uomo inviato dalla Provvidenza ['a man sent by Providence'], Giammaria in his poem suggests that Constantine and Mussolini are both figures in God's ordained plan for Rome and the Christian world.

It seems that by the time Giammaria wrote his poem, the model of Constantine competed in some circles with that of Augustus as an emblem of the kind of leadership that was capable of restoring political and social stability and prosperity after a period of dangerous unrest. In Giammaria's poem, Augustus is almost entirely absent, while Constantine is set up in this role. Thus, Giammaria's representation of the Arch of Constantine shows how he melds lateantique, early Christian Rome with Mussolini's 'Third Rome', while presenting both Constantine's reign and Mussolini's regime as crucial moments in the city's providential history. By suggesting a direct 'prophetic' relationship between Constantine and Mussolini, Giammaria moreover offers an alternative to the 'Augustan' model which, by the time he wrote his poem, was becoming increasingly popular among Fascist ideologues. Both of these tactics illustrate the poet's sophisticated and slightly unconventional response to the regime's most recent and ongoing urbanistic interventions.

\section{5}

Ara Dei Caduti Fascisti

The Ara dei caduti fascisti [Altar to the Fallen Fascists], to which we now turn, appears as one of the first monuments of Giammaria's tour (Figure 5). Unlike many of the other landmarks in Capitolium Novum, which date to classical and late antiquity, the middle ages, and the period of the Risorgimento, the altar is a very recent addition to the cityscape. But as we shall see, even this newly erected monument had been set up with the intention of reframing its historical surroundings in a Fascist mould. Giammaria's representation of the monument, on the other hand hints at its place in a different teleological narrative for the city of Rome. We cite Giammaria's depiction of the altar in full:

44 'l'uomo inviato dalla Provvidenza che rivela a noi stessi i nuovi destini; il gran padre, il pontefice della Patria alfine ritrovata; un novello Costantino', cited in Guasco, 'Il "nuovo Costantino", 473. The image of Mussolini as uomo della Provvidenza was made popular by the Pope himself. Right after the signing of the Lateran Pacts, Pius XI celebrated the event with a speech in which he said that 'maybe a man was needed like the one [Mussolini] that Providence sent us'. Ceci, The Vatican, 134. On the reception of the Lateran Pacts among Catholics, see David I. Kertzer, The Pope and Mussolini: The Secret History of Pius XI and the Rise of Fascism in Europe (Oxford: Oxford University Press, 2014), 105-113. 


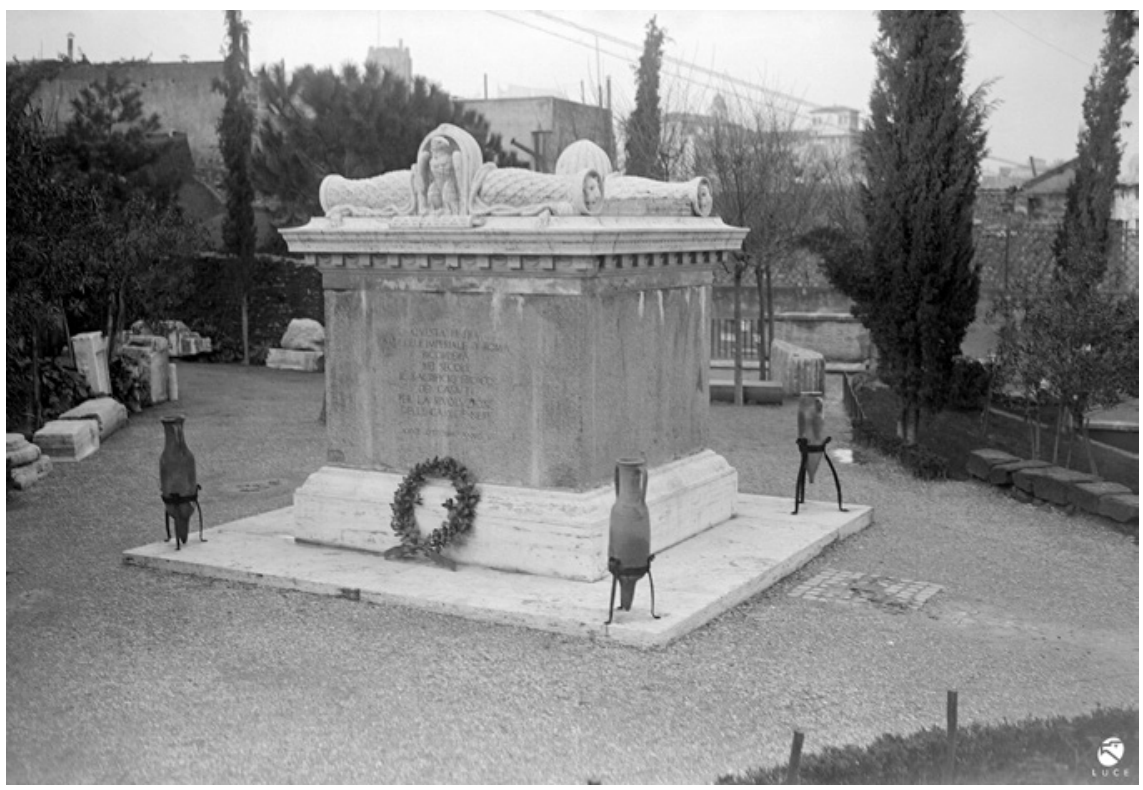

FIG. 5 The Ara dei cadutifascisti on the Capitoline Hill (13 March 1928).

SOURCE: ARCHIVIO LUCE, A00002344.

Here a curved slope, which gently goes around the hill, extends to the shady top and a peaceful retreat. Here a new altar, which rises up between the laurel-trees, celebrated with sacred devotion and an eternal cult, has deservedly been dedicated, as the Dux wished, to the strength of the unsubdued youth, which, slain by an unspeakable crime, shed its blood and offered its life to the Fatherland. Here then it is now honoured with dignity, so that it may become both an example and a warning for future generations. If you prefer to pause briefly on these summits and look into the distance opposite you, you see the rooftops, built on many levels and arranged as if in the shape of a theatre. Behold, the proud Quirinal hill is dominated by a huge structure and magnificently carries majestic palaces. ${ }^{45}$

CN 63-77: Clivus hic incurvus, montem qui leniter ambit, / Culmen ad umbrosum tendit, placidumque recessum. / Hic, nova quae lauros inter supereminet ara, / Relligione sacra et cultu celebrata perenni, / Ut voluit Dux, est merito sacrata juventae / Viribus invictae, infando quae crimine caesa, / Obtulerat Patriae, perfuso sanguine, vitam. / Hic honor est igitur digne nunc redditus illi, / Gentibus exemplum ut fiat monitumque futuris. / Si super haec breviter consistere culmina malis / Et studeas te contra impellere lumina longe / Pluribus exstructa in gradibus fastigia tecti / Cernis et in forma veluti digesta theatri. / Ecce Quirinalis dominatur mole superbus / Collis et augustas referens regaliter aulas. 
The Ara dei caduti fascisti had been erected in 1926 in memory of the 'martyrs' of Fascism: those who had died in the erection or defense of the Fascist order. The monument immediately acquired a central role for the Fascists' rituals and commemorations. ${ }^{46}$ A newly constructed road along the back of the Capitoline Hill (the Via dell'Ara Littoria, today the Via San Pietro in Carcere) led up to a viewing platform just below the summit of the Campidoglio, behind the Palazzo Senatorio and overlooking the Forum Romanum. It was known at the time as Giardino della Vittoria [Garden of Victory] - the recessus placidus of Giammaria's poem (line 64). The official journal of the Fascist Governatorato, entitled Capitolium, stressed the sacred aura and ancient glory of the location: 'the sacred place whence the voice of Rome once spread over the world with the rumble of thunder. 47 The altar itself consisted of an imposing block of rose-red granite that once supported an Egyptian obelisk erected in the Horti Sallustiani under Emperor Aurelian. ${ }^{48}$ Its ancient provenance underlined both the symbolic and the physical association with Roman antiquity, while its red color visually suggested the theme of bloodshed and martyrdom. During its inauguration, incense burned to accentuate the sacral nature of the ceremony. ${ }^{49}$ The monument was dismantled after the fall of the regime, and its main component, the red granite block, was moved a short distance to a republican brick wall, with the Fascist inscription turned on its head and facing the wall. ${ }^{50}$

Giammaria again makes some specific and telling choices in describing this strange monument, which come into sharper focus when we consider his words in relation to the altar's inscription. In 1927, an epigraph was carved on the Ara to commemorate 'the heroic sacrifice of those who died for the

46 See Painter, Mussolini's Rome, 35-36; Vittorio Vidotto, 'I luoghi del fascismo a Roma,' Dimensione e problemi della ricerca storica, no. 2 (2005): 40-41; Sylvia Diebner, 'Le trasformazioni di un blocco di granito: Da sostegno di un obelisco antico all' "Ara dei caduti per la rivoluzione fascista" sul Campidoglio (1926-1944),' Bollettino della Commissione Archeologica Comunale di Roma 112 (2011): 153-170; and most recently Arthur Weststeijn, 'Egyptian Memorials in Modern Rome: The Dogali Obelisk and the Altar of the Fallen Fascists,' in The Iseum Campense from the Roman Empire to the Modern Age: Temple - Monument - Lieu de Mémoire (Papers of the Royal Netherlands Intitute in Rome), ed. Miguel John Versluys, Kristine Bülow Clausen, and Giuseppina Capriotti Vittozzi (Rome: Edizioni Quasar, 2019), 331-347.

47 'M. B', 'Il Giardino della Vittoria sul Campidoglio,' Capitolium 1, no. 3 (1925): 155.

48 On the history of the obelisk see Diebner, 'Le trasformazioni,' 153-155 and Kim J. Hartswick, The Gardens of Sallust: A Changing Landscape (Austin: University of Texas Press, 2013): $5^{2-58 .}$

49 Weststeijn, 'Egyptian Memorials,' 343.

5o Forimages of the Fascist monumentand the dismantled base, see Diebner, 'Le trasformazioni,' 163,166 and Hartswick, The Gardens, 57. On the marginalization of the memorial in postwar Italy, see Weststeijn, 'Egyptian Memorials,' 346-347. 
black-shirt revolution'.51 The Ara was thus framed as the explicitly Fascist counter-part to the more broadly nationalist Tomb of the Unknown Soldier. ${ }^{52}$ Interestingly, in Capitolium Novum, the specificity of the actual inscription is answered by a vaguer, more inclusive nationalist rhetoric. While acknowledging Mussolini's role in erecting the memorial, Giammaria broadens its cultic function to the Italian youth who had 'shed its blood and offered its life to the Fatherland' - rather than specifically for the Fascist cause. ${ }^{53}$ This is a significant rhetorical move, albeit one of shifting nuances, rather than of opposition or dissent. Giammaria reframes the Ara as a national rather than exclusively Fascist memorial, while at the same time emphasizing that this was exactly 'as the Dux wished. 54

The theme of martyrdom in this passage reminds the reader of the passage of the Colosseum discussed above. The themes of martyrs' sacrifice and bloodshed, of brave opposition against morally depraved enemies, as well as of sacred memory and everlasting reward, unite the two monuments in the poem, and Giammaria invites us to read the two passages against each other through this thematic and verbal reprisal. ${ }^{55}$ But if we do so, we cannot but notice that the poet's language is noticeably less emphatic in the passage on the Ara dei caduti fascisti than it is in the Colosseum passage: martyrs of the state receive only a fraction of the praise lavished on their Christian equivalents. By turning the altar's martyrs into (admittedly lesser) counterparts of the martyrs of the Colosseum, Giammaria incorporates the caduti fascisti into a larger teleological narrative of a Christian Rome on its way to salvation. Potentially 'pagan' associations of the altar with its political rituals are effectively downplayed, while Fascism's cult of its martyrs is subsumed into the (Christian) history of Rome and the Fatherland.

\section{Conclusion}

Once the monument has been described, the guide encourages us to linger on the platform, pointing out the majestic view over the city (lines $72-77$ ). By

51 The original text run as follows: QVESTA PIETRA / SV COLLE IMPERIALE DI ROMA / RICORDERÀ / NEI SECOLI / IL SACRIFICIO EROICO / DEI CADVTI / PER LA RIVOLVZIONE / DELLE CAMICIE NERE / XXVIII OTTOBRE ANNOV.Cf. Diebner, 'Le trasformazioni,' 166, fig. 19 .

52 Diebner, 'Le trasformazioni,' $156-157$.

$53 \quad \mathrm{CN}, 66-71$.

$54 \mathrm{CN}, 67$.

$55 C N$ 65, 67: ara...sacrata - cf. $C N$ 131: sacra arena; $C N$ 67-68: iuventae /Viribus invictae - cf. CN 125,126: Christiadae...invicti; $C N$ 69: perfuso sanguine - cf. $C N$ 121: sanguis perfusus. 
encouraging us to survey the city from a point which is also a focal area of the Fascist cult, the narrator reminds us of the intended purpose of the viewing platform with the monumental Fascist altar: to demonstrate the subordination of the entire city of Rome, with allits histories, layers and complexities, its old buildings, recent excavations and additions, to the Fascist gaze. And yet, Capitolium Novum complicates its readers' view of the heart of Rome and its symbolism.

Are we really gazing at 'Fascist' Rome from the top of the 'New Capitoline'? In the case of the Colosseum, the column of Trajan, the Arch of Constantine, and the Ara dei caduti fascisti, we have seen how Giammaria's poem encourages the reader-viewers of historic Rome to contextualize the story of the city within a narrative of Christian salvation. Even the word novus, which in other in Fascist Latin poems tends to be used for the renewal of ancient Rome in contemporary Italy, receives historical nuancing in Giammaria's poem. In Capitolium Novum, it refers not only to the Fascist building works in the preceding years and to the renewal and reinvigoration of Italy through the Fascist movement. Instead, throughout the poem, the vocabulary of novelty is applied consistently and emphatically to the rise of Christianity. This can be seen most clearly in a key passage and the central section of the poem, where nova signacula (182), nova doctrina (185), renovata templa (186) and novo numine (190) all refer to the rise of the new faith and its victory over ancient superstition. ${ }^{56}$ While the poet praises the Dux for the current renewal of the country, he also asks his readers to understand this renewal as part of a larger, all-encompassing, spiritual renewal, to which the city of Rome and its many monuments bear eloquent testimony.

Ultimately, Giammaria's literary Rome-tour should be understood in the broader context of the politically and ideologically loaded question of what we see, or should see, when we look at the city, what 'Rome' really stands for, and what, therefore, 'Romanness', romanità, should signify. Giammaria's

$5^{6} \quad$ CN 181-191: Attamen hic quoque nec desunt, de sorte superna, / Quae nova conclamant Christi signacula legem: / Numina muta manent gentis, nec thura cremantur, / Templaque divorum vacuo squalore fatiscunt. / At nova quae mentes agitat doctrina per orbem / Has coluit sacras aras renovataque templa, / Rectas perque vias animos adducit ad astra. / Jure igitur sacrae quae tollunt culmina ad auras / Aedes, quaeque sacrae crepitant nunc thuribus arae, / Sanctius atque novo divo sub numine surgunt, / Mentibus et signant vitae simulacra futurae. ['But nevertheless, the new signs which announce the heavenly law of Christ are not absent: the deities of the people remain silent, nor is incense burned, and the temples of the gods fall apart, abandoned and dirty. But the new doctrine that excites minds across the world honoured these sacred altars and the renewed temples, and leads souls to the stars along the right paths. For this reason the sacred temples which lift their tops into the air, and the sacred altars which now crackle with incense, rise more solemnly and under the divine will of a new god, and impress visions of future life in our minds.'] 
representation of the city is rooted in a long-standing literary genre which lends itself perfectly to his sophisticated reflection on the interrelation between and respective importance of different historical moments. His choice and use of the Latin language in itself conveys a complex message of mediated universalism. In a medium and language accessible only (especially in its subtleties) to a relatively small circle of specialists, Giammaria's poem nonetheless engages with important contemporary concerns of Fascist propaganda and ideology. In particular, as we have argued, Capitolium Novum resonates with the efforts of intellectuals and scholars gathered around Galassi Paluzzi's Institute of Roman Studies in trying to broaden the scope of Fascist romanità, to mediate between the claims of Fascist and Catholic universalism, and ultimately to effect a cultural reconciliation between Fascism and Catholicism.

\section{Acknowledgement}

We are grateful to the guest editors of this issue for the opportunity to publish this article and for their editorial work. We would also like to thank the audiences at the workshop 'What Remains? Fascist and National Socialist Antiquities and Materialities from the Interwar Era to the Present Day' at Cambridge (8 June 2018) and the masterclass 'Art and Rhetoric in Roman Literature' at the Norwegian Institute in Rome (1-3 October 2018) for inspiring discussions and helpful comments. The anonymous readers provided many constructive suggestions which we have gladly followed, and Jan Willem Drijvers and Arthur Weststeijn offered helpful advice on a number of points. Student assistant Hylke de Boer has supported our work in a variety of ways. We would also like to thank the 'Geodienst' (University of Groningen) for providing the map cited as figure 1. Our research is part of Anchoring the Fascist Revolution (www.anchoring-fascism.com), a sub-project of the national research agenda Anchoring Innovation of the Dutch National Research School oikos. 